\title{
PREVALENCE AND RISK FACTORS OF \\ HELICOBACTER PYLORI AND INTESTINAL \\ PROTOZOAL INFECTIONS AMONG SEWAGE
}

WORKERS IN MANSOURA, EGYPT

\author{
By \\ Foad $\mathrm{M} \mathrm{F}^{*}$ and Awadalla $\mathrm{NJ}^{* *}$ \\ "Department of Clinical Pathology, ${ }^{* *}$ Department of Public Health and Preventive Medicine, \\ Faculty of Medicine, Mansoura University, Egypt.
}

\begin{abstract}
:
Background: The occupational risks for sewage exposed workers for developing Helicobacter pylori and protozoal infections have received a little attention. Studies revealed that $\mathrm{H}$. pylori organism discharged in stool and could be transmitted through contaminated water and consequently could present a significant health problem to sewage workers.

Objective: to estimate the prevalence of $\mathrm{H}$. pylori and protozoal infections and to assess the gastrointestinal symptoms and hematological profile among sewage workers. Also, to determine the risk factors of $\mathrm{H}$. pylori infection.

Methods: A comparative cross sectional study was conducted for 60 workers working in Mansoura sewage treatment plant and maintenance of sewage collection system and 30 matched unexposed referents working as food handlers and supervisors in Mansoura University Hospitals. Demographic, occupational and gastrointestinal symptoms data were collected. Also, laboratory procedures include, complete blood count, stool analysis and culture and detection of $\mathrm{H}$. pylori antigen using immunochromatographic rapid assay were done.
\end{abstract}

Results: The prevalence of $\mathrm{H}$. pylori in sewage workers was $56.7 \%$ compared to $16.7 \%$ among the control group with highly statistically significant difference between both groups. Heartburn with or without epigastric pain was the only significant gastrointestinal symptoms among sewage workers (43.3\%) compared to comparison group (20.0\%). Prevalence of E. histolytica in both exposed and comparison groups were high (65\% 
\& 56.6\%) respectively without statistically significant difference. Giardia Lamblia was more frequent in sewage workers $(20.0 \%)$ than comparison workers $(10.0 \%)$ without significant difference. Stool culture was negative for pathogenic organisms (Salmonella or Shigella) in both groups. The risk of H. pylori was significantly higher among workers with poor compliance with personal protective equipment (PPE) $(\mathrm{OR}=3.00,95 \% \mathrm{CI}: 1.07-10.35)$, workers with duration of work $>20$ years $(\mathrm{OR}=4.71$, 95\% CI: 1.10-20.20), workers older than 45 years (OR=4.27, 95\%CI: $1.00-18.15)$ and low educated workers (OR=11.2, 95\%CI:1.23-101.89). On logistic regression analysis, the independent predictors of $\mathrm{H}$. pylori infection in sewage workers were low education $(\mathrm{OR}=43.35)$ and poor compliance with PPE $(\mathrm{OR}=5.21)$.

Conclusion: H. pylori infection and heartburn with or without epigastric pain are significant health problems in the studied sewage workers. On logistic regression, low education and poor compliance with PPE were the significant predictors of $\mathrm{H}$ pylori infection in sewage workers.

Key words: H. pylori - gastrointestinal symptoms- protozoal infection - sewage workers.

\section{Introduction}

The working conditions of the sewage workers have remained virtually unchanged. Apart from the social atrocities that these workers face, they are exposed to many health problems by virtue of their occupation (Tiwari, 2008). Sewage workers are potentially exposed to a wide variety of organic and inorganic pollutants, to human and animal infectious and non infectious (e.g. endotoxins) biological agents (Douwes et al., 2001). Faeces and waste water are possible routes of transmission (Brown, 2000) by inhalation, ingestion by hand- to- mouth (feco-oral route) or skin absorption (Hooste et al.,2010).

Helicobacter pylori (H. pylori) is a bacterium associated with peptic ulcer disease, gastric cancer, mucosa associated lymphoid tissue (MALT) lymphoma (Suerbaum and Michetti, 2002) and is now considered a class 1 carcinogen by the International Agency for Research on Cancer (Tiwari, 2008). There are other infections like Hepatitis E virus (HEV) (Jeggli et al.,2004) , Leptospirosis (De Serres et al., 1995) and Hepatitis A virus (HAV) which has been commonly detected among sewage workers (Keeffe, 2004).

Epidemiological studies have demonstrated that the prevalence of $\mathrm{H}$. pylori infection increases with advancing age and is considered a public health problem in developing countries and among low socioeconomic level populations, probably due to conditions that favor the acquisition of infection such as precarious 
hygiene, crowded living conditions, absence or deficiency of sanitation and poor hygiene (Graham et al., 1991).

The isolation of $\mathrm{H}$. pylori from faeces has been used to argue for the fecal- oral route of transmission (Thomas et al., 1992). H. pylori has also been isolated from dental plaque and saliva, suggesting that the bacterium may be acquired by the oraloral route (Ferguson et al.,1993; Majmudar et al.,1990). Also, there are reports about isolation of $\mathrm{H}$. pylori from faeces (Kelly et al.,1994) and a risk of contamination by water (Klein et al., 1991).

The occupational risk for sewage exposed workers for developing $\mathrm{H}$. pylori and protozoal infections have received little attention. So, our study aimed to estimate the prevalence of $\mathrm{H}$. pylori and protozoal infections among sewage workers. Also, to study the gastrointestinal symptoms and the hematological profile among this vulnerable group of workers. Additionally, to assess the risk factors for developing H. pylori infection and to recommend measures to minimize the risk of these infections.

\section{Subjects and methods}

\section{Study design:}

A comparative cross sectional study was conducted during the period from
January to August 2010. The exposed group included 60 sewage workers in Mansoura sewage treatment plant and maintenance of sewage collection system and the control group consisted of 30 food workers in Mansoura University Hospital. The study was approved by the Research Ethics Committee of Mansoura University.

Study population and location:

The exposed group consisted of 60 sewage workers, 41 of them were from the different job categories at risk of exposure to raw sewage in the main sewage treatment station in Mansoura City; 3 laboratory workers, 28 workers clean and maintain the sedimentation tanks, and 10 workers who maintain equipments and pumps. Another group of 19 exposed workers were selected from sewage workers who clean and maintain the sewage collection system in Mansoura city. Both exposed populations were morning shift workers due to logistic causes (suitable time for sample taking, transport of samples and availability of the lab for analysis). All morning shift workers were invited to share in the study, nearly ninety and eighty percent respectively responded to share in the study. The most important causes of non responders were; absence of interest and fear from blood sampling. 
The unexposed referents group consisted of 30 food handlers and supervisors in Mansoura University Hospitals matched with exposed workers for age, socioeconomic status, smoking and duration of work through group matching. Both groups gave written informed consent to participate in the study.

\section{Study tools}

All recruited subjects were subjected to the following procedures:

1. A specially designed questionnaire concerning the worker's demographic data including age, sex, residence, marital status, smoking habits, occupation and work practice.

2. Compliance with the personal protective equipment (PPE) as overall, plastic boots, plastic gloves and masks was assessed using scoring system depending on time of wearing; most of time score (2), some of time score (1) and never score (0). Poor compliance considered when total score less than (4).

3. Information concerning the gastrointestinal symptoms.

4. Stool and EDTA blood samples for laboratory assessment.

\section{Laboratory procedures:}

1) Complete blood count (CBC)

2) Stool culture: about 3-4 loopfuls $(1 \mathrm{gm})$ of stool was added to $20 \mathrm{ml}$ selenite broth(Oxoid) and incubated at 370C over night then plated out on MacConkey's agar (Oxoid) for 24 hours. The isolated colonies were identified by gram stain and manual biochemical reaction on Triple Sugar Iron agar (TSI), Christensen's urea agar and Simmon' citrate agar (Oxoid).

3) Stool analysis: using the spontaneous sedimentation method. Fifty grams of feces were mixed with about $100 \mathrm{ml}$ of tap water and sieved through a $2 \mathrm{ml}$ mesh sieve, washed with $50 \mathrm{ml}$ of water and pressed with a spatula to recover as much of the water as possible. After $40 \mathrm{~min}$, the supernatant was decanted until $50 \mathrm{ml}$ remained. The beaker was refilled to $200 \mathrm{ml}$ with tap water and the suspension allowed standing. After $40 \mathrm{~min}$, the supernatant was decanted until $30 \mathrm{ml}$ remained, and $1 \mathrm{ml}$ was examined (in about 200 ul aliquots) microscopically at 100x magnification.

4) Detection of H. pylori antigen in stool: this immunochromatographic rapid assay (CAL-TECH DIAGNOSTICS, INC. Chino, CA 91710, USA). 
H.pyloriAntigen Band Test is a sandwich solid phase immunochromatographic assay. An aliquot of diluted stool sample is added to the sample well of the test cassette. The sample flows through a label pad containing $\mathrm{H}$. pylori antibody (Ab) coupled to red colored colloidal gold. If the sample contains $\mathrm{H}$. pylori antigens, the antigen (Ag) will bind to the $\mathrm{Ab}$ coated on the colloidal gold particles to form AgAb-Gold complexes. These complexes move on the nitrocellulose membrane by capillary action toward the test line region on which H. pylori specific antibodies are immobilized. As the complexes reach the test line, they will bind to the $\mathrm{Ab}$ on the membrane in the form of a line. A second red control line will always appear in the result window to indicate that the test has been correctly performed and the test device functions properly. If $\mathrm{H}$. pylori $\mathrm{Ag}$ is not present or lower than the detection limit of the test only the control line will be visible. If the control line doesn't develop, the test is invalid.

\section{Statistical analysis}

Data were analyzed using Statistical Package for Social Sciences (SPSS) version 11 (SPSS Inc., Chicago, IL, USA). The study groups were compared regarding demographic criteria, gastrointestinal symptoms and laboratory data using the chi-square test for qualitative variables and student's t-test for quantitative variables. Significant factors predicting of $\mathrm{H}$. pylori infection on bivariate analysis were entered into multivariate logistic regression analysis to find out the independent predictors of $\mathrm{H}$. pylori infection. The odds ratio and $95 \%$ confidence interval were calculated. $\mathrm{P} \leq 0.05$ was considered statistically significant.

\section{Results}

Table 1 summarizes the demographic data of the studied groups. Most of the studied subjects were young adult, non smokers, from rural areas and married. The majority of sewage workers were education less than secondary school $(71.7 \%)$ and $<10$ years employment (53.3\%). No statistically significant differences were found between sewage workers and unexposed referents.

Importantly and as shown in Table 2 heart burn with or without epigastric pain symptoms were significantly higher in sewage workers $(43.3 \%)$ compared with the unexposed referents $(20.0 \%)(\mathrm{P} \leq 0.05)$. Other gastrointestinal symptoms showed no statistically significant difference between both groups.

Table 3 demonstrates the prevalence of $\mathrm{H}$. Pylori in sewage workers was $56.7 \%$ and there was highly statistically 
significant difference compared to unexposed referents $(\mathrm{P} \leq 0.001)$. Most of both groups were positive for E. histolytica $(65 \%$ \& 56.6\%) respectively without statistically significant difference. Giardia Lamblia was slightly more frequent in sewage group than referent group but also without significant difference $(\mathrm{P}>0.05)$. Stool culture was negative for Salmonella or Shigella (pathogenic organisms) in both studied groups. No statistically significant differences were found between the studied groups $(\mathrm{P}>0.05)$ regarding hemoglobin level, red blood cells (RBCs) and white blood cells (WBCs) counts on the other hand, platelets count was significantly lower among sewage workers compared to controls.

The highest prevalence of $\mathrm{H}$. Pylori was shown in workers in sedimentation tank workers and sewage pipes cleaner $(41.2 \%$ \& 32.4\%) respectively and those who are living in rural area and of low education $(50 \% \& 67.6 \%)$ respectively. By univariate analysis the risk of $\mathrm{H}$. pylori was significantly higher among workers with poor compliance with PPE (OR=3.00, 95\%CI: 1.07-10.35), workers with duration of work $>20$ years $(\mathrm{OR}=4.71, \quad 95 \%$ CI:1.10-20.20) ,workers older than 45 years $(\mathrm{OR}=4.27,95 \% \mathrm{CI}: 1.00-18.15)$ and low educated (less than secondary school) workers $\quad(\mathrm{OR}=11.2,95 \% \mathrm{CI}: 1.23-101.89)$ table 4 .

The independent predictors of $\mathrm{H}$. pylori infection among sewage workers as revealed by logistic regression analysis are presented in Table 5. Low education and poor compliance with $\mathrm{PPE}(\mathrm{OR}=43.35$ and 5.21 respectively) were the only significant predictors of $\mathrm{H}$. pylori infection among sewage workers.

Lastly, as shown in Table 6 there was a highly statistically significant association between heart burn with or without epigastric pain and infection with $\mathrm{H}$. pylori $(\mathrm{P} \leq 0.001)$ in the exposed group. On the other hand, there were no statistically significant associations between hematological parameters as anemia, thrombocytopenia and infection with $\mathrm{H}$. pylori. 
Table 1. Socio-demographic criteria of the sewage workers compared to unexposed referents.

\begin{tabular}{|c|c|c|c|c|}
\hline $\begin{array}{l}\text { Socio-demographic } \\
\text { criteria }\end{array}$ & $\begin{array}{l}\text { Sewage workers } \\
\qquad(\mathrm{n}=60)\end{array}$ & $\begin{array}{l}\text { Referents } \\
\qquad(\mathbf{n}=\mathbf{3 0})\end{array}$ & $\begin{array}{c}\text { Test of } \\
\text { significance }\end{array}$ & p-value \\
\hline 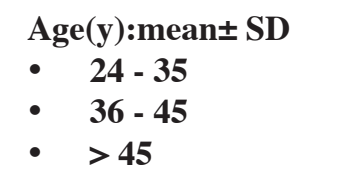 & $\begin{array}{c}37.68 \pm 10.81 \\
31(51.7 \%) \\
14(23.3 \%) \\
15(25.0 \%)\end{array}$ & $\begin{array}{c}37.80 \pm 6.34 \\
10(33.3 \%) \\
13(43.3 \%) \\
7(23.3 \%)\end{array}$ & $\begin{array}{l}t=0.054 \\
\chi^{2}=4.16\end{array}$ & $\begin{array}{l}0.95 \\
0.125\end{array}$ \\
\hline $\begin{array}{l}\text { Smoking } \\
\text { Non-smokers } \\
\text { Smokers }\end{array}$ & $\begin{array}{l}42(70.0 \%) \\
18(30.0 \%)\end{array}$ & $\begin{array}{c}23(76.7 \%) \\
7(23.3 \%)\end{array}$ & $\chi^{2}=0.443$ & 0.621 \\
\hline $\begin{array}{l}\text { Residence } \\
\text { Rural } \\
\text { Suburban } \\
\text { Urban }\end{array}$ & $\begin{array}{c}35(58.3 \%) \\
7(11.7 \%) \\
18(30.0 \%)\end{array}$ & $\begin{array}{l}21(70.0 \%) \\
3(10.0 \%) \\
6(20.0 \%)\end{array}$ & $\chi^{2}=1.238$ & 0.53 \\
\hline $\begin{array}{l}\text { Marital status } \\
\text { Married } \\
\text { Single }\end{array}$ & $\begin{array}{l}52(86.7 \%) \\
8(13.3 \%)\end{array}$ & $\begin{array}{l}26(86.7 \%) \\
4(13.3 \%)\end{array}$ & $\chi^{2}=0.11$ & 0.74 \\
\hline $\begin{array}{l}\text { Education } \\
<\text { secondary } \\
\text { Secondary } \\
>\text { secondary }\end{array}$ & $\begin{array}{c}43(71.7 \%) \\
10(16.7 \%) \\
7(11.7 \%)\end{array}$ & $\begin{array}{l}15(50.0 \%) \\
7(33.33 \%) \\
8(26.66 \%)\end{array}$ & $\chi^{2}=7.643$ & 0.054 \\
\hline Duration of employm & ent (years) & & & \\
\hline $\begin{array}{c}\text { mean } \pm \text { SD } \\
<10 \\
10-20 \\
>20\end{array}$ & $\begin{array}{c}12.37 \pm 11.15 \\
32(53.3 \%) \\
14(23.3 \%) \\
14(23.3 \%)\end{array}$ & $\begin{array}{c}15.36 \pm 6.20 \\
9(30.0 \%) \\
14(46.7 \%) \\
7(23.3 \%)\end{array}$ & $\begin{array}{l}\mathrm{t}=1.365 \\
\chi^{2}=5.24\end{array}$ & 0.072 \\
\hline
\end{tabular}


Table 2. Frequency of gastrointestinal symptoms in sewage workers compared to unexposed referents

\begin{tabular}{|lcccc|}
\hline Gastrointestinal symptoms & $\begin{array}{c}\text { Sewage workers } \\
(\mathbf{n = 6 0})\end{array}$ & $\begin{array}{c}\text { Referents } \\
(\mathbf{n = 3 0})\end{array}$ & $\begin{array}{c}\text { Test of } \\
\text { significance }\end{array}$ & p-value \\
\hline Heartburn \pm epigastric pain & $26(43.3 \%)$ & $6(20.0 \%)$ & $\chi^{2}=3.79$ & $0.05^{*}$ \\
\hline Colic & $10(16.7 \%)$ & $10(33.33 \%)$ & $\chi^{2}=3.21$ & 0.07 \\
\hline Changes in bowel habit & $3(5.0 \%)$ & $3(10.0 \%)$ & $\chi^{2}=0.80$ & 0.396 \\
\hline Distension & $8(13.3 \%)$ & $2(6.7 \%)$ & $\chi^{2}=0.9$ & 0.486 \\
\hline
\end{tabular}

*Statistically significant $(\mathrm{P} \leq 0.05)$

Table 3. Comparison between sewage workers and unexposed referents regarding stool and hematological parameters

\begin{tabular}{|lcccc|}
\hline $\begin{array}{l}\text { Stool and hematological } \\
\text { parameters }\end{array}$ & $\begin{array}{c}\text { Sewage workers } \\
(\mathbf{n}=\mathbf{6 0})\end{array}$ & $\begin{array}{c}\text { Referents } \\
(\mathbf{n}=\mathbf{3 0})\end{array}$ & $\begin{array}{c}\text { Test of } \\
\text { significance }\end{array}$ & p-value \\
\hline Helicobacter pylori & $34(56.7 \%)$ & $5(16.7 \%)$ & $\chi^{2}=13.03$ & $0.000^{* *}$ \\
\hline Stool examination: & $39(65.0 \%)$ & $17(56.6 \%)$ & $\chi^{2}=0.590$ & 0.442 \\
E. histolytica & $12(20.0 \%)$ & $3(10.0 \%)$ & $\chi^{2}=1.44$ & 0.230 \\
G. lambylia & & & & \\
\hline Stool culture & $23(38.3 \%)$ & $14(46.7 \%)$ & $\chi^{2}=0.28$ & 0.59 \\
Proteus & $28(46.7 \%)$ & $8(26.7 \%)$ & $\chi^{2}=3.33$ & 0.07 \\
Klebsilla & $9(15.0 \%)$ & $8(26.7 \%)$ & $\chi^{2}=1.78$ & 0.18 \\
E.coli & $12.52 \pm 1.04$ & $12.10 \pm 1.55$ & $\mathrm{t}=1.53$ & 0.130 \\
\hline Hb & $4.37 \pm 0.30$ & $4.26 \pm 0.54$ & $\mathrm{t}=1.18$ & 0.242 \\
RBCs & $38.16 \pm 3.44$ & $38.05 \pm 5.17$ & $\mathrm{t}=0.12$ & 0.903 \\
Ht & $5.75 \pm 2.39$ & $6.55 \pm 2.80$ & $\mathrm{t}=1.42$ & 0.158 \\
WBCs & $183.65 \pm 37.35$ & $214.76 \pm 49.3$ & $\mathrm{t}=2.56$ & $0.012^{*}$ \\
Platelets & & & \\
\hline
\end{tabular}

a No pathogenic organisms were detected in both groups.

*Statistically significant $(\mathrm{P} \leq 0.05)$

** Highly statistically significant $(\mathrm{P} \leq 0.001)$ 
Table 4. Risk factors of Helicobacter pylori infection among sewage workers.

\begin{tabular}{|c|c|c|c|c|}
\hline & $\begin{array}{c}\text { Positive } \\
\text { Helicobacter } \\
\text { pylori } \\
(\mathrm{n}=34)\end{array}$ & $\begin{array}{l}\text { Negative } \\
\text { Helicobacter } \\
\text { pylori } \\
(\mathrm{n}=26)\end{array}$ & OR(95\% CI) & p-value \\
\hline $\begin{array}{ll}\text { Type of work: } \\
- & \text { Laboratory workers } \\
- & \text { Sedimentation tank workers } \\
- & \text { Maintenance } \\
- & \text { Sewage pipes cleaner }\end{array}$ & $\begin{array}{c}0(0.00 \%) \\
14(41.2 \%) \\
8(23.5 \%) \\
12(35.29 \%)\end{array}$ & $\begin{array}{l}3(11.53 \%) \\
14(53.8 \%) \\
2(7.70 \%) \\
7(26.92 \%)\end{array}$ & $\begin{array}{c}- \\
\mathrm{r} \\
4.00(0.72-22.28) \\
1.71(0.52-5.64)\end{array}$ & $\begin{array}{c}- \\
- \\
0.09 \\
0.37\end{array}$ \\
\hline $\begin{array}{l}\text { PPE adequate compliance } \\
\text { PPE poor compliance }\end{array}$ & $\begin{array}{l}17(50.0 \%) \\
17(50.0 \%)\end{array}$ & $\begin{array}{l}20(76.93 \%) \\
6(23.07 \%)\end{array}$ & $\begin{array}{c}\mathrm{r} \\
3.00(1.07-10.35)\end{array}$ & $0.03^{*}$ \\
\hline $\begin{array}{l}\text { Non smokers } \\
\text { Smokers }\end{array}$ & $\begin{array}{l}21(61.8 \%) \\
13(38.2 \%)\end{array}$ & $\begin{array}{l}21(80.8 \%) \\
5(19.2 \%)\end{array}$ & $\begin{array}{c}r \\
2.60(0.78-8.59)\end{array}$ & 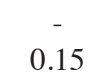 \\
\hline $\begin{array}{l}\text { Duration of work (years): } \\
<10 \\
10-20 \\
>20\end{array}$ & $\begin{array}{l}14(41.2 \%) \\
9(26.5 \%) \\
11(32.4 \%)\end{array}$ & $\begin{array}{l}18(69.2 \%) \\
5(19.2 \%) \\
3(11.5 \%)\end{array}$ & $\begin{array}{c}\mathrm{r} \\
2.31(0.63-8.47) \\
4.71(1.10-20.20)\end{array}$ & $\begin{array}{c}- \\
0.19 \\
0.02 *\end{array}$ \\
\hline $\begin{array}{l}\text { Age (years): } \\
24-35 \\
36-45 \\
>45\end{array}$ & $\begin{array}{c}15(44.1 \%) \\
7(20.6 \%) \\
12(35.3 \%)\end{array}$ & $\begin{array}{l}16(61.5 \%) \\
7(26.9 \%) \\
3(11.5 \%)\end{array}$ & $\begin{array}{c}\mathrm{r} \\
1.07(0.3-3.77) \\
4.27(1.00-18.15)\end{array}$ & $\begin{array}{c}- \\
0.92 \\
0.05^{*}\end{array}$ \\
\hline $\begin{array}{l}\text { Residence: } \\
\text { - Rural } \\
\text { - Suburban } \\
\text { - Urban }\end{array}$ & $\begin{array}{l}17(50.0 \%) \\
4(11.8 \%) \\
13(38.2 \%)\end{array}$ & $\begin{array}{l}18(69.2 \%) \\
3(11.5 \%) \\
5(19.2 \%)\end{array}$ & $\begin{array}{c}\mathrm{r} \\
1.41(0.27-7.26) \\
2.75(0.81-9.38)\end{array}$ & $\begin{array}{l}- \\
0.67 \\
0.10\end{array}$ \\
\hline $\begin{array}{l}\text { Education: } \\
\text { - <Secondary } \\
\text { - Secondary } \\
\text { - > Secondary }\end{array}$ & $\begin{array}{c}28(82.35 \%) \\
5(14.70 \%) \\
1(2.94 \%)\end{array}$ & $\begin{array}{l}15(57.69 \%) \\
5(19.23 \%) \\
6(23.07 \%)\end{array}$ & $\begin{array}{c}11.2(1.23-101.89) \\
6.0(0.52-69.76) \\
\mathrm{r}\end{array}$ & $\begin{array}{c}0.03 * \\
0.31 \\
-\end{array}$ \\
\hline
\end{tabular}

$\mathrm{OR}=$ odds ratio, $\mathrm{CI}=$ Confidence interval, $\mathrm{r}=$ reference group

*Statistically significant $(\mathrm{P} \leq 0.05)$

PPE: Personal protective equipment 
Table 5. Logistic regression analysis of independent predictors of Helicobacter pylori infection among sewage workers

\begin{tabular}{|c|c|c|c|}
\hline Predictors & $\boldsymbol{\beta}$ & $\mathbf{P}$ & OR $(95 \%$ CI $)$ \\
\hline $\begin{array}{l}\text { PPE compliance: } \\
\text { - Adequate compliance } \\
\text { - Poor compliance }\end{array}$ & 1.65 & $0.01 *$ & $\begin{array}{c}\mathrm{r} \\
5.21(1.49-18.20)\end{array}$ \\
\hline $\begin{array}{l}\text { Education: } \\
\text { - <Secondary } \\
\text { - Secondary } \\
\text { - >Secondary }\end{array}$ & $\begin{array}{l}3.76 \\
1.25 \\
-\end{array}$ & $\begin{array}{c}0.008 * \\
0.19 \\
-\end{array}$ & $\begin{array}{c}43.35(2.61-717.99) \\
3.49(0.52-23.25) \\
\mathrm{r}\end{array}$ \\
\hline Constant & -1.76 & 0.07 & - \\
\hline
\end{tabular}

$\mathrm{OR}=$ odds ratio, $\mathrm{CI}=$ Confidence interval, $\mathrm{r}=$ reference group

*Statistically significant $(\mathrm{P} \leq 0.05)$

PPE: Personal protective equipment

Table 6. Gastrointestinal symptoms and hematological abnormalities in H. pylori positive and negative sewage workers.

\begin{tabular}{lcccc}
\hline & $\begin{array}{c}\text { Positive } \\
\text { Helicobacter } \\
\text { pylori } \\
(\mathrm{n}=34)\end{array}$ & $\begin{array}{c}\text { Negative } \\
\text { Helicobacter } \\
\text { pylori } \\
(\mathrm{n}=26)\end{array}$ & $\begin{array}{c}\text { Test of } \\
\text { significance }\end{array}$ & p-value \\
\hline Heartburn+epigastric pain & $21(61.8 \%)$ & $5(19.2 \%)$ & $\chi^{2}=10.85$ & $0.001 * *$ \\
\hline Colic & $7(20.6 \%)$ & $3(11.5 \%)$ & $\chi^{2}=0.869$ & 0.49 \\
\hline Changes in bowel habits & $1(2.9 \%)$ & $2(7.7 \%)$ & $\chi^{2}=0.70$ & 0.57 \\
\hline Distension & $5(14.7 \%)$ & $3(11.5 \%)$ & $\chi^{2}=0.12$ & 1.00 \\
\hline Anemia & $22(64.7 \%)$ & $12(46.2 \%)$ & $\chi^{2}=2.06$ & 0.19 \\
\hline Thrombocytopenia & $2(5.9 \%)$ & $4(15.4 \%)$ & $\chi^{2}=1.47$ & 0.38 \\
\hline
\end{tabular}

** Highly Statistically significant $(\mathrm{P} \leq 0.001)$ 


\section{Discussion}

H. pylori is associated with high gastrointestinal tract morbidity (Graham et al.,1991). In the present study, the prevalence of $\mathrm{H}$. pylori in sewage workers was $56.7 \%$ compared to $16.7 \%$ among unexposed referents with highly statistically significant difference between both groups. This was to some extent in accordance with the findings of Jeggli et al. (2004) who detected the prevalence of IgG $\mathrm{Ab}$ to $\mathrm{H}$. pylori which was $43 \%$ but lower prevalence than our study was observed by Hooste et al.(2010) who found that the prevalence was $16.7 \%$ compared to $13.6 \%$ among the control group. In some poor locality in Northeastern Brazil, the prevalence of $\mathrm{H}$. pylori in two studies were very high $(80 \%, 62.9 \%)$ (Rodrigues et al., 2005; Rodrigues et al.,2005). This much variation in the prevalence of $\mathrm{H}$. pylori may be due to locality or environmental variation or due to difference in the method of the detection of $\mathrm{H}$. pylori as well as poor control measures for exposure to raw sewage particles .

Heartburn with or without epigastric pain were significantly higher in our sewage workers group $(43.3 \%)$ as compared with the unexposed referents. This was in accordance with Friis et al.(1998) and
Hooste et al.(2010) who found that, the sewage workers were affected more often by peptic ulcers during their present jobs than the referents. In contrast to these findings, Jeggli et al.(2004) had found that the prevalence of work related epigastric pain and or abdominal cramps among workers in the past four weeks were always low. The high prevalence of H. pylori in the present study among sewage workers and the significant association between $\mathrm{H}$. pylori and heartburn and epigastric pain may give an explanation for this observation as it was suggested that $\mathrm{H}$. pylori infection is related to increased risk for peptic ulcers (Fennerty, 1994; Salih et al., 2007). On the other hand, the other gastrointestinal symptoms showed no significant difference between sewage workers and unexposed referents. This also, was in agreement with the study conducted by Friis et al. (1998).

There was high prevalence of E. histolytica in the studied and unexposed referents. Egypt has high rates of asymptomatic infection of $\mathrm{E}$. histolytica (Stauffer et al., 2006) . G. lamblia was slightly more frequent in sewage group than referent group with insignificant difference between both groups. G. lamblia has been detected before among sewage workers (Heap and McCulloch, 1991). Moreira et al.(2005) showed an association between 
H. pylori infection and the presence of $G$. lamblia in faeces. It is well known that G. lamblia is transmitted by the fecaloral route and thus, this association may indicate that both microorganisms share this common route of transmission. One may also argue that gastric giardiasis increases the susceptibility to $H$. pylori infection. Doglioni et al.(1992) found $\mathrm{H}$. pylori infection in $90.2 \%$ Italic patients with gastric giardiasis. Alternatively, H. pyloriinduced chronic gastritis may increase the susceptibility to G. lamblia infection.

In the present study, the highest prevalence of $H$. pylori was shown on sewage workers who live in rural area and of low education level. However, the risk of $\mathrm{H}$. pylori infection among them were not found to increase significantly with type of work, smoking habit or residence of the workers. These were in agreement with Rodrigues et al.(2005) who studied H. pylori infection in adults from a poor community in Northeastern Brazil. On the other hand, the risk of $H$. pylori was significantly higher among workers with low education, poor compliance with PPE, duration of work $>20$ years and age $>45 y$ ears. This was in agreement with Hooste et al.(2010) who reported a high risk of H. pylori seropositive status with longer duration of work and this was against the result of a study done by Jeggli et al.(2004) who found, no significant association with exposure duration. On logistic regression low education and poor compliance with PPE were the only significant predictors of infections. An increasing body of published scientific evidence suggests that exposure to environmental and occupational hazards is not randomly distributed in the population, but tends to be disproportionately concentrated among communities of people of low education and socioeconomic level, as well as among low-income workers and workers of low education. This could be explained by unawareness about the health hazards, neglecting protective measures and inadequate healthcare (Institute of Medicine, 1999).

In the present study, the prevalence of anemia and thrombocytopenia in $\mathrm{H}$. pylori positive were $64.7 \%$ and $5.9 \%$ respectively with no statistically significant differences between both groups. Many studies were reported iron deficiency anemia (IDA) associated with H.pyloriinfection(Annibale et al., 2000; Cardenas et al.,2006). Choe et al.(1999) showed a benefit for H. pylori treatment for patients with unexplained IDA who have H. pylori gastritis. IDA is the simple result of an imbalance between iron loss and absorption. Gastric function with hydrochloric and ascorbic acid is essential 
for iron absorption. Some strains of $\mathrm{H}$. pylori are able to acquire iron, competing with the host. A large percentage of patients with atrophic body gastritis $(\mathrm{ABG})$ develop IDA and $61 \%$ of them are H. pylori positive. There was evidence suggests that $\mathrm{H}$. pylori infection could cause IDA in the absence of peptic ulcer or other upper GIT bleeding lesions. Gastritis extending to the corpus and a high bacterial load are features of these patients (Annibale et al.,2000).

Gasbarrini et al.(1998) were described an improved platelet count in patients with idiopathic thrombocytopenic purpura (ITP) after the eradication of H. pylori infection. Also, many studies detected regression of autoimmune thrombocytopenia after eradication of $\mathrm{H}$. pylori (Gasbarrini et al., 1998; Kohda et al., 2002).

\section{Conclusion and recommendations}

H.pylori infection and heartburn with or without epigastric pain are significant health problems in the studied sewage workers. Low education and poor compliance with PPE were the only significant predictors for $\mathrm{H}$ pylori infection in sewage workers. G. lamblia was slightly more frequent in sewage group than referent unexposed group with insignificant difference between the two groups.
According to the results of the present study, pre-employment training and health education programs should be done and repeated periodically to raise the awareness of sewage workers about the hazards of direct exposure to raw sewage and the value of proper compliance with PPE to minimize the risk of H. pylori infection. Medical care for detection and treatment of $\mathrm{H}$. pylori and other positive finding specially for those complaining with heartburn and or epigastric pain, workers with long duration of employment, poor compliance with PPE and old age also, to apply screening program for early detection of H.pylori.

\section{References}

1. Annibale B, Capurso G, Martino G, Grossi C and Delle Fave G (2000). Iron deficiency anemia and Helicobacter pylori infection. Int $\mathbf{J}$ Antimicrob Agents. 16(4):515-9.

2. Brown LM. Helicobacter pylori: epidemiology and routes of transmission (2000). Epidemiol Rev.22:283-97.

3. Cardenas VM, Mulla ZD, Ortiz M and Graham DY (2006). Iron Deficiency and Helicobacter ylori infection in the United States. Am J Epidemiol.163:127-134.

4. Choe YH, Kim SK, Son BK, Lee DH, Hong YC and Pai SH (1999). Randomized placebo-controlled trial of Helicobacter pylori eradication for iron-deficiency anemia in preadolescent children and adolescents. Helicobacter.4:135-9.

5. De Serres G, Levesque B, Higgins R, Major M, Laliberte D, Boulianne N, et al.(1995) Need for vaccination of sewer workers against leptospirosis and hepatitis A. Occup Environ Med.52:5057. 
6. Doglioni C, De Boni M, Cielo R, Laurino L, Pelosio P, Braidotti P, Viale G (1992). Gastric giardiasis . J Clin Pathol. 45:964-967.

7. Douwes J, Mannetie A, Heederik D (2001). Work- related symptoms in sewage treatment workers. Ann Agric Environ Med. 8:39-45.

8. Fennerty MB (1994). Helicobacter pylori. Arch Intern Med. 154: 721-727.

9. Ferguson DA Jr, Li C, Patel NR, Mayberry WR, Chi DS, Thomas E (1993). Isolation of Helicobacter pylori from saliva. J Clin Microbiol .31:2802-2804.

10. Friis L, Agreus L and Edling C (1998). Abdominal symptoms among sewage workers . Occup. Med. 48: 251-53

11. Gasbarrini A, Franceschi F, Tartaglione R, Landolfi R, Pola P and Gasbarrini G (1998). Regression of autoimmune thrombocytopenia after eradication of Helicobacter pylori. Lancet.352:878.

12. Graham DY, Malaty HM, Evans DG, Evans DJ, Klein PD, Adam E (1991). Epidemiology of Helicobacter pylori infection in an asymptomatic population in the United States. Gastroenterology.100:1495-1500.

13. Heap BJ and McCulloch MLB (1991). Giardiasis and occupational risk in sewage workers. Lancet. 338:1152.

14. Hooste WV, Charlier AM, Rotsaert P, Bulterys S, Moens G, Sprundel MV and Schryver AD (2010). Work-related Helicobacter pylori infection among sewage workers in municipal wastewater treatment plants in Belgium. Occup Environ Med. 67:91-97.

15. Institute of Medicine (1999). Toward Environmental Justice: Research, Education, and Health Policy Needs. Washington, DC: National Academy Press.

16. Jeggli S, Steiner D, Joller H, Tschopp A, Steffen R, Hotz P (2004). Hepatitis E, Helicobacter pylori and gastrointestinal symptoms in workers exposed to waste water. Occup Environ Med. 61:622-627.
17. Keeffe EB (2004). Occupational risk for hepatitis A: A literature-based analysis. J Clin Gastroenterol. 38:440-8.

18. Kelly SM, Pitcher MCL, Farmery SM, Gibson GR (1994). Isolation of Helicobacter pylori from feces of patients with dyspepsia in the United Kingdom. Gastwentervlogy. 107: 1671-74.

19. Klein PH, Graham DY, Gaillour A, Opekun AR, O'Brian Smith E (1991). Water source as risk factor for Helicobacter pylori infection in Peruvian children. Lancet. 337: 1503-1506.

20. Kohda K, Kuga T, Kogawa K, Kanisawa Y, Koike K, Kuroiwa G, Hirayama Y, Sato Y and Niitsu Y (2002). Effect of Helicobacter pylori eradication on platelet recovery in Japanese patients with chronic idiopathic thrombocytopenic purpura and secondary autoimmune thrombocytopenic purpura. British $\mathrm{J}$ of Haematology. 118:584-588.

21. Majmudar P, Shah SM, Dhunjibhoy KR, Desai HG (1990). Isolation of Helicobacter pylori from dental plaques in healthy volunteers. Indian $\mathbf{J}$ Gastroenterol. 9:271-272.

22. Moreira ED, Nassri VB, Santos RS, Matos JF, de Carvalbo WA, Silvani CS and e Sant,Ana CS (2005). Association of Helicobacter pylori infection and giardiasis: Results from a study of surrogate markers for fecal exposure among children. World J of Gastroenterol. 11(18):2759-2763.

23. Rodrigues MN, Queiroz DM, Rodrigues RT, Rocha AM, Luz CR and Braga LL (2005). Prevalence of Helicobacter pylori infection in Fortaleza, Northeasstern Brazil. Rev Saude Publica. 39(5):847-9.

24. Rodrigues MN, Queiroz DM, Rodrigues RT, Rocha AM, Neto MB and Braga LL (2005). Helicobacter pylori infection in adults from a poor urban community in Northeastern Brazil: Demographic, Lifestyle and Environmental factors. Braz J Infect Dis. 9(5):405-410.

25. Salih, Barik; M Fatih Abasiyanik, Nizamettin Bayyurt, Ersan Sander (2007). H pylori infec- 
tion and other risk factors associated with peptic ulcers in Turkish patients: A retrospective study. World Journal of Gastroenterology .13 (23): 3245-3248

26. Stauffer W, Abd-Alla M and Ravdin J (2006). Prevalence and incidence of Entamoeba histolytica Infection in South Africa and Egypt. Arch Med Res. 37 (2): 266-9.
27. Suerbaum S and Michetti P (2002). Medical progress: Helicobacter pylori infection. $\mathrm{N}$ Engl J Med. 347:1175-86

28. Thomas JE, Gibson GR, Darboe MK, Dale A, Weaver LT (1992). Isolation of Helicobacter pylori from human faeces. Lancet. 340:1194-1195.

29. Tiwari RR (2008). Occupational health hazards in sewage and sanitary workers. Indian J Occup Environ Med. 12(3):112-115. 